\title{
A Brave New World in State Aid?
}

The European Commission has just started a new mandate under the presidency of Ursula von der Leyen, with a new College of Commissioners. Since the European Commission plays a pivotal role in the area of State aid, it is worth wondering about the possible changes and evolutions that we could expect in this new mandate.

Margrethe Vestager remains in charge of Competition - including State aid - while assuming at the same time the role of Executive Vice-President for a Europe fit for the Digital Age. One could therefore expect, at least at first sight, a certain degree of continuity in State aid. If this were the case, we would probably see more State aid investigations of tax rulings granted by some Member States to certain large multinationals. After all, in the absence of big legislative changes, this line of tax ruling cases were, by far, the main political priority in the previous mandate.

However, despite the continuity of Mrs Vestager, this situation is likely to change due to different factors, both internal and external. The Commission has just appointed Olivier Guersent as new General Director for Competition. Carles Esteva was appointed as Deputy General Director in charge of State aid only a few months ago. Both are respected and experienced officials with long careers in different areas of competition policy. Their presence will surely have an impact on State aid policy.

We dare to think that State aid law should also have a certain impact on State aid policy. The Commission has in recent times lost quite a few cases before the EU Courts. These defeats include two of the three judgments adopted so far in the tax rulings cases, suggesting that political priorities do not always guarantee a legal victory. Both EU Courts seem to be paying increasing attention - quite rightly in our opinion — to issues like a correct analysis of selectivity or advantage, or the correct allocation of the burden of proof in State aid cases. At stake are the proper definitions of the rights and obligations of the Commission, of the Member States and of the undertakings operating in the internal market. This evolution would probably require a more careful investigation and a more detailed motivation of State aid decisions in the future. This should not be a problem, since - thanks to the 'modernization' of State aid in recent years - the Commission got rid of $95 \%$ of the previous notifications, thereby liberating abundant workforce in order to deal with the remaining cases.

Climate change is nowadays present everywhere. Even though State aid policy has been a pioneer in taking it on board a while ago, we should expect an even greener version of it to take shape in the coming mandate. This is a development that we would support, provided that it is done in a consistent way.

More worryingly, recent external pressure by some Member States - in particular France and Germany - and some constituencies, mostly large European companies, is also trying to have an impact on the shaping of future competition policy in general and also of State aid policy in particular. The recent calls in favour of a reinforced link between industrial policy and competition or for a more flexible application of the competition rules are hardly different from the old familiar support to European champions allegedly necessary to compete on the global stage. 
The new President of the Commission recently sent 'mission letters' to the different members of the College explaining the political priorities of the Commission in general and also in the specific area of responsibility of each member. It is interesting to read the 'mission letter' addressed to Mrs Vestager and to examine what it says about State aid. ${ }^{1}$ This may give us some preliminary indications of how the Commission is planning to navigate these troubled waters in the coming years.

The President requests all the commissioners 'to focus on the application and enforcement of EU law' within their respective fields. While the Commission 'should provide support and continuous guidance to Member States on implementation' (something that the past 'State aid modernization' already did), it also has to 'be ready to take swift action if EU law is breached'. Without being restricted to it, this mandate applies with particular pertinence in the area of State aid.

The specific mandates of Mrs Vestager are less obvious and produce more mixed feelings.

A review of the competition rules appears high on the agenda. This will cover, among other things, 'the review of State aid rules and guidance'. This in itself is not at all surprising or worrying, since State aid has lived in a quasi-permanent state of review for the last 25 years. Indeed, the Commission has recently undertaken a so-called 'fitness review' with the declared objective of revisiting once more the different set of rules and guidelines that were the object of the latest 'modernization'.

The problem rather lays in the declared objectives of the coming new (re)modernization wave. According to the mission letter, 'Competition will have an important role in our industrial strategy. The competitiveness of our industry depends on a level playing field that provides business with the incentive to invest, innovate and grow. EU State aid rules should support this where there are market failures and the need to strengthen value chains. As part of this, you should continue to work with the Member States to make the most of Important Projects of Common European Interest.'

Evoking 'industrial strategy' or the 'competitiveness' of European industry as reasons to again modify the State aid rules suggests that the direction of travel would be towards increased flexibility and therefore towards more State aid, certainly not the opposite. The increasing mobilization of public funds at the national level would be the logical consequence, in the hope that this would leverage increased private investments resulting in economic growth. By the same token, one would expect that the additional State aid towards certain objectives and undertakings would reinforce the competiveness of European companies (or 'champions') in the global arena.

This may be true, but it is not all the truth. The missing part is realizing that, precisely because of its importance for the industrial strategy, these measures would automatically create severe distortions to competition within the internal market. Indeed, some Member States have much deeper pockets than others. As a consequence, the undertakings based in the former would be much more likely to have access to the announced rainfall of State aid than those based in the latter. Like the competition between European companies and those based in third countries, competition among European companies also depends on a level playing field that provides business with the incentive to invest, innovate and grow'. The Commission would be

1 <https://ec.europa.eu/commission/commissioners/sites/comm-cwt2019/files/commissioner_mission_letters/mission-letter-margrethe-vestager _2019_en.pdf>. 
wrong to sacrifice the latter - whose preservation is its core mission according to the Treaty in the pursuit of the former.

According to the Treaty, State aid policy is a balancing exercise between, on the one hand, the expected positive effects of the aid and, on the other, its unavoidable negative effects on competition in the internal market. This is the very reason why State aid control exists; it is also the reason why it was entrusted to a supranational institution like the Commission. State aid policy has always been more sensitive towards the positive effects of many sorts of State aid, in particular of those pursuing public goals (like regional policy or Services of General Economic Interest,...) or mitigating market failures (environmental protection, R\&D\&I, ...). Its attention to the negative effects on the internal market has been more modest in recent years. However, the Commission could never turn a totally blind eye to the negative part of the equation, because its role is to ensure the balance between both the positive and the negative sides. Indeed, if this mission were no longer required, one wonders what would still be the raison d'être of State aid control at the EU level.

The mission letter also refers cryptically to 'the need to strengthen value chains' and encourages its addressee 'to make the most of Important Projects of Common European Interest' (IPCEI). The practical implication of these statements may be better understood in the light of the Decision adopted by the Commission only a few days later, approving $€ 3.200$ million of State aid 'for a pan-European research and innovation project in all segments of the battery value chain'.2 Seven Member States were formally involved, but the three larger ones granted $86 \%$ of the aid. The beneficiaries were one car producer and various other companies active in the batteries sector. One cannot deny the strategic importance of batteries for the development of the car industry, among others, but it would be strange to believe that such an aid would not distort competition in that same sector. We will therefore read with interest, once it becomes public, the reasoning of the Decision on the balancing between the positive and negative effects of the aid.

In our opinion, neither Europe nor its industries would benefit from a subsidy race with third countries. Such a race is only likely to produce losers in the long run. However, in the short run it is true that certain third countries see things otherwise and are subsidizing their national champions and distorting competition in the global markets. Europe has always advocated for some kind of multilateral control of subsidies at the global level as a much better option. In an ideal world, the WTO discipline - covering only goods and not services should be completed and enhanced. Unfortunately, in the real world, we are seeing rather the opposite.

It is therefore only logical that the EU prepares the necessary instruments to face this problem by itself. The mission letter contains an interesting idea in this respect: 'As part of the industrial strategy, you should develop tools and policies to better tackle the distortive effects of foreign state ownership and subsidies in the internal market.'

In our opinion, the EU has the necessary know how to put into place a legal instrument against subsidies granted by third countries to its companies to the extent that they produce distortions of competition in Europe. It would be a logical extension of the existing internal State aid regime. The main practical difficulty would lie in the remedies, since recovery would be difficult to implement in such scenarios. One would probably need to think of some kind

$2<$ https://ec.europa.eu/commission/presscorner/detail/en/ip_19_6705>. 
of countervailing duties instead. The compatibility of such a regime with WTO rules would need to be analysed and ensured in due course. In any case, this idea seems promising and worth exploring.

In our opinion, EU State aid policy has been a key element for the functioning of the internal market, thereby fulfilling reasonably well over the years the core mission entrusted by the Treaties. It may be appropriate to use it also as complement to other legitimate policy objectives provided this does not enter into conflict with its core mission. The Commission should also keep in mind that, on top of being a policy, State aid is also a part of EU Law. As President von der Leyen as rightly reminded us in her mission letter, the Commission must 'focus on the application and enforcement of EU Law'. We hope that these missions will be successfully fulfilled. 